\title{
Management methodology of effective development of furniture industry enterprises
}

\author{
Borisov Alexey Nikolaevich \\ SRO VGASU-story \\ 394061, 4a, Truda Ave \\ Russia, Voronezh \\ e-mail: kingoao@mail.ru
}

\author{
Bezrukova Tatyana Lvovna \\ Voronezh State University of Forestry and Technologies \\ named after G.F. Morozov \\ 394087, 8, Timiryazeva street \\ Russia, Voronezh \\ e-mail: kingoao@mail.ru
}

\author{
Shanin Igor Igorevich \\ Voronezh State University of Forestry and Technologies named after G.F. Morozov \\ 394087, 8, Timiryazeva street \\ Russia, Voronezh
}

\begin{abstract}
Dynamic development of the Russian market of furniture products, tightening of competition in this market branch attach particular importance to the application of advanced management methods to optimize the production process, which leads to an increase in the competitiveness of enterprises. In the context of formation of effective directions for the country's development, improvement of management of effective development of enterprises, their provision with various innovative types of resources and technologies for the optimal use of all the reserves of enterprises acquire special importance. The most accessible is a comprehensive approach to the management of effective development of an industrial enterprise, which consists in improving a management mechanism of effective enterprise development.
\end{abstract}

Effective development of the enterprise as a managed system is built on the part of its full financial and economic independence. All the internal issues of its activity are solved by enterprise independently, selling products, organizing accounting and reporting. Enterprise sells its products at prices that are built on financial and economic contracts concluded with buyers.

Keywords - dynamic development; management; economic independence; styling; managed system

\section{INTRODUCTION}

It is necessary to emphasize the importance of the fact that effective development is primarily an economic category; therefore, a significant place is given to scientists whose scientific research lies in the field of economics in its development. But, at the moment, the studied category has not still been comprehensively studied.

According to V.N. Parahina, the goal of effective development of an enterprise is a certain result, depending on multiplicity and diversity of factors. Consequently, with a more detailed study of the factors' influence on the magnitude of the result, the forecast of its possible achievement is an accurate and reliable one.
In general consideration, in the works of V.O. Pozdeev, management of effective development of enterprises is considered as a developed system, bound by certain processes and phenomena. Effective development of enterprises is considered as an indicator of development, the most effective development makes $3 / 4$ of the most important incentive for enterprises

When considering various criteria, it becomes clear that the criteria may not fully reflect the existing situation of effective development of enterprises. When considering profitability indicators, for example, only estimates of financial results of enterprises are determined and information on comprehensive presentation of effective development of enterprises is not provided.

\section{RESULTS AND DISCUSSION}

Based on the study conducted by the authors, results, indicators of evaluation of tools and methods used to manage effective development at Russian enterprises have been obtained.

Using the proposed system of indicator-criteria for assessing effective development and selected indicator, the authors propose the following deterministic factor model for effective development:

IA

$0.251 \times \mathrm{A} 1+0.041 \times \mathrm{A} 2+0.313 \times \mathrm{A} 3+0.251 \times \mathrm{A} 4+0.105 \times \mathrm{A} 5+0.1$ $51 \times \mathrm{A} 6$,

where IA - private indicator of effective development

A number of necessary coefficients of a deterministic factor model is determined through analysis at the enterprises under study. Coefficients can be adjusted in the process of using the proposed model at various industrial enterprises, taking into account their production features. 
The formula used to calculate the partial indicators of effective development has the following form:

$$
\mathrm{Ai}=\sum \mathrm{xijyij}
$$

where $x i j$ - the value of the $j$-th indicator of the $i$-th criterion of effective development of enterprises;

yij - weight of the $\mathrm{j}$-th indicator of the $\mathrm{i}$-th criterion of effective development of enterprises.

TABLE I. DESCRIPTION OF GROUPS OF INDICATORS FOR ASSESSING THE EFFECTIVE DEVELOPMENT OF ENTERPRISES

\begin{tabular}{|c|c|c|c|c|c|c|}
\hline $\begin{array}{l}\text { The effect of } \\
\text { variance on } \\
\text { the identified } \\
\text { factors e } 1 \\
\text { and e } 2\end{array}$ & \multicolumn{2}{|c|}{ A1 } & \multicolumn{2}{|c|}{$\mathrm{A} 2$} & \multicolumn{2}{|c|}{ A3 } \\
\hline $\begin{array}{c}\text { Evaluation of } \\
\text { variance } \\
\text { effects }\end{array}$ & e1 & $\mathrm{e} 2$ & e1 & $\mathrm{e} 2$ & $\mathrm{e} 1$ & e2 \\
\hline VSi & 2.521 & 1.742 & 0.812 & 0.301 & 1.341 & 2.501 \\
\hline \multirow[t]{2}{*}{$\mathrm{VSi} / \lambda \mathrm{r}$} & 0.345 & 0.141 & 0.117 & 0.031 & 0.181 & 0.191 \\
\hline & \multicolumn{2}{|c|}{ A4 } & \multicolumn{2}{|c|}{$\mathrm{A} 5$} & \multicolumn{2}{|c|}{ A6 } \\
\hline VSi & 1.021 & 4.881 & 0.032 & 0.971 & 0.071 & 0.784 \\
\hline $\mathrm{VSi} / \lambda \mathrm{r}$ & 0.141 & 0.661 & 0.004 & 0.141 & 0.011 & 0.061 \\
\hline
\end{tabular}

Based on the data in Table 1, it can be concluded that effective organization in the production process, effective use of material, raw materials and labor resources in the production process (A1) have a significant impact on the effective use of resources in the current operations of enterprises $(\mathrm{e} 1)$; factors of effective planning and volume of performance of production plans and sales of manufactured products (A2); factors that characterize the effective allocation of costs included in the cost of production (A3). Effective management of the current operations of enterprises (e2) is influenced by the following factors: characterizing effective financial planning, profitability, and financial sustainability of enterprises (A4), effective management of enterprise managers (A5), and efficient business activity of enterprises (A6). The obtained conclusions correspond to the classification proposed in Table 1.

Thus, based on the obtained results, the authors have formed an integrated indicator of the management of effective enterprise development. This indicator includes indicators:

$\mathrm{A} 4=\mathrm{f}(\mathrm{x} 31 \mathrm{y} 31 \ldots \mathrm{x} 38 \mathrm{y} 38)$, A5 $=f(x 41 y 41 \ldots x 43 y 43), \quad A 6=f(x 51 y 51), \quad A 7=f(x 61 y 61)$. The calculation formula for the indicator is presented below:

$$
\mathrm{I}_{\mathrm{MA}}=0.251 \times \mathrm{A}_{1}+0.313 \times \mathrm{A}_{3}+0.105 \times \mathrm{A}_{5}+0.151 \times \mathrm{A}_{6},
$$

The calculation formula for the partial indicators of effective development is presented in the following form:

$$
\mathrm{Ai}=\sum \mathrm{xij}^{\prime}{ }^{\mathrm{yij}},
$$

xi' - the value of indicators of the system for assessing the effective development;

$$
\text { yi - weight of the indicator. }
$$

The presented deterministic factorial model of effective development is reflected in the calculation of integral indicator, including a system of indicators which are criteria for assessing the effective development of enterprises. For the correctness of the values of indicators-criteria, it is necessary to use the indicators-criteria located in the same interval. When calculating the factor model, it is necessary to give the values of all indicators in the interval of $[-1 ; 1]$. Each indicator, when calculating, determines its importance: possible influence of the factor on the effective development of enterprises. Each weight of the factor is obtained through an expert survey of professional servants who work at the enterprises under investigation. When you bring the indicator criteria to the total necessary interval boarder, you need to apply normalization by linearly converting all values so that these values are in the right interval range:

$$
\frac{x_{i j}=x_{i j}-F}{C},
$$

where $x i j:-j$-th coordinate of the $\mathrm{i}$-th vector,

$\mathrm{F}$ and $\mathrm{C}$ - defined, predetermined values, conditionally called as specific coatings. These values are determined on the basis of statistical characteristics in the distribution of empirical samples: statistical rationing, or selected by means of a priori considerations: standardization.

A multidimensional data cloud can have several coverings of statistical normalization, while transformation of variation series of each selected indicator occurs using a sample in statistical characteristics. This fact indicates of the geometric center used in the multidimensional cloud of $\mathrm{X}$ data points. This acts as the average of the selected features using $\mathrm{K}$ scale that characterizes maximum distribution in the data cloud:

$$
\begin{gathered}
\bar{X}=\frac{1}{N} \sum_{i=1}^{N} X i, \\
K=\max _{i=1 . . N}\|X i-\bar{X}\| .
\end{gathered}
$$

Taking into account that calculations were carried out using the correlation matrix, then in the obtained integral coefficient all xi and yi are centralized and reduced to the necessary level of normalization.

Main components selected in the process of factor analysis and classes of indicator-criteria by the authors made it possible to confirm the formula presented by the authors for calculating the integral index of effective development of enterprises. On the basis of this, the authors analyzed the activities of enterprises based on selected indicators-criteria; the results of the calculations can be seen in Table 2. 
TABLE II. RESULTS OF CALCULATIONS OF INDICATORS-CRITERIA FOR EFFECTIVE DEVELOPMENT OF ENTERPRISES

\begin{tabular}{|c|c|c|c|c|c|c|}
\hline \multirow{3}{*}{$\begin{array}{c}\text { Indica- } \\
\text { tor's } \\
\text { name }\end{array}$} & \multicolumn{6}{|c|}{ Enterprises } \\
\hline & \multicolumn{2}{|c|}{ AO Grafskoe } & \multicolumn{2}{|c|}{$\begin{array}{l}\text { OOO PC } \\
\text { Angstrem }\end{array}$} & \multicolumn{2}{|c|}{$\begin{array}{c}\text { OOO Furniture } \\
\text { Comfort }\end{array}$} \\
\hline & 2015 & 2016 & 2015 & 2016 & 2015 & 2016 \\
\hline 1 & 2 & 3 & 4 & 5 & 6 & 7 \\
\hline X01 & -0.221 & 0.097 & -0.912 & -0.612 & 0.813 & 0.765 \\
\hline $\mathrm{X} 02$ & -0.612 & 1.212 & -1.314 & -0.612 & 0.317 & 0.921 \\
\hline $\mathrm{X} 03$ & 1.181 & 0.765 & -0.414 & -0.671 & -0.541 & -0.561 \\
\hline X04 & 0.501 & 0.412 & -1.274 & 0.416 & -0.055 & 0.031 \\
\hline X05 & -0.731 & 0.765 & 0.413 & -0.981 & 0.341 & 0.441 \\
\hline X06 & -0.471 & 0.118 & 0.971 & 0.178 & -0.453 & -0.367 \\
\hline X07 & -0.911 & -0.213 & 0.431 & 0.257 & 0.301 & 0.378 \\
\hline $\mathrm{X} 08$ & -0.801 & -0.765 & 0.953 & 1.812 & -0.371 & -0.461 \\
\hline X09 & -0.213 & -0.128 & 0.946 & 0.937 & -0.904 & -0.651 \\
\hline $\mathrm{X} 11$ & -0.621 & 0.345 & -0.601 & 1.231 & -0.884 & 0.435 \\
\hline $\mathrm{X} 12$ & 0.401 & -0.789 & -0.239 & 0.712 & -0.071 & 0.117 \\
\hline $\mathrm{X} 13$ & 0.803 & 0.573 & -1.214 & 0.546 & -0.723 & 0.157 \\
\hline X21 & 1.007 & 0.352 & -0.078 & -0.915 & -0.169 & -0.371 \\
\hline $\mathrm{X} 22$ & -0.321 & 0.889 & -0.084 & 1.431 & -1.238 & -0.781 \\
\hline $\mathrm{X} 23$ & 0.841 & -0.776 & -0.091 & 0.317 & -0.271 & -0.116 \\
\hline $\mathrm{X} 24$ & 0.421 & -0.798 & 0.009 & 0.641 & -0.082 & 0.081 \\
\hline $\mathrm{X} 25$ & 0.134 & -0.313 & 0.418 & -0.941 & -0.067 & 0.731 \\
\hline $\mathrm{X} 26$ & 0.431 & 0.378 & 0.108 & -0.952 & -0.035 & -0.054 \\
\hline $\mathrm{X} 27$ & -0.789 & 0.591 & 0.541 & 1.341 & -0.917 & -0.831 \\
\hline $\mathrm{X} 28$ & 0.257 & 0.054 & -0.521 & -0.915 & 0.573 & 0.751 \\
\hline X31 & -0.812 & -0.901 & 0.148 & 0.519 & 0.561 & 0.614 \\
\hline X32 & -0.311 & -0.781 & 0.913 & 0.125 & 0.614 & -0.671 \\
\hline X33 & -0.213 & -0.200 & 0.307 & -0.843 & 0.517 & 0.427 \\
\hline X34 & -0.452 & -0.445 & -0.438 & 0.124 & 0.408 & 0.878 \\
\hline X35 & -0.761 & -0.617 & 0.801 & 1.261 & -0.313 & -0.487 \\
\hline X36 & 0.923 & 1.291 & -0.543 & -0.178 & -0.765 & -0.761 \\
\hline X37 & -0.818 & -0.872 & 0.280 & 0.709 & 0.412 & 0.514 \\
\hline X38 & 0.312 & -0.318 & -0.871 & -0.453 & 0.376 & 0.915 \\
\hline $\mathrm{X} 41$ & -0.031 & 0.061 & 0.059 & -0.918 & 0.419 & 0.451 \\
\hline X51 & -0.278 & -0.578 & 0.571 & -0.371 & 0.787 & -0.321 \\
\hline X61 & 0.314 & -0.112 & -0.050 & -0.076 & 0.806 & -0.918 \\
\hline $\begin{array}{c}\text { The } \\
\text { value } \\
\text { of } \\
\text { integra } \\
1 \\
\text { coeffic } \\
\text { ient }\end{array}$ & $\begin{array}{c}- \\
0.0741 \\
281\end{array}$ & $\begin{array}{c}- \\
0.0091 \\
792\end{array}$ & $\begin{array}{c}0.00644 \\
58\end{array}$ & $\begin{array}{c}- \\
0.04567 \\
41\end{array}$ & $\begin{array}{c}0.05431 \\
45\end{array}$ & 0.0490878 \\
\hline
\end{tabular}

Based on the analysis carried out on three examined enterprises, the authors reflect the effective development of enterprises in Figures 1, built on the results in calculating the integrated indicator of effective development of activities at each of the three enterprises. Taking into account the general conclusions about the current state of the enterprises, the authors have concluded that enterprises effectively use tools and methods to manage the effective development of enterprises.

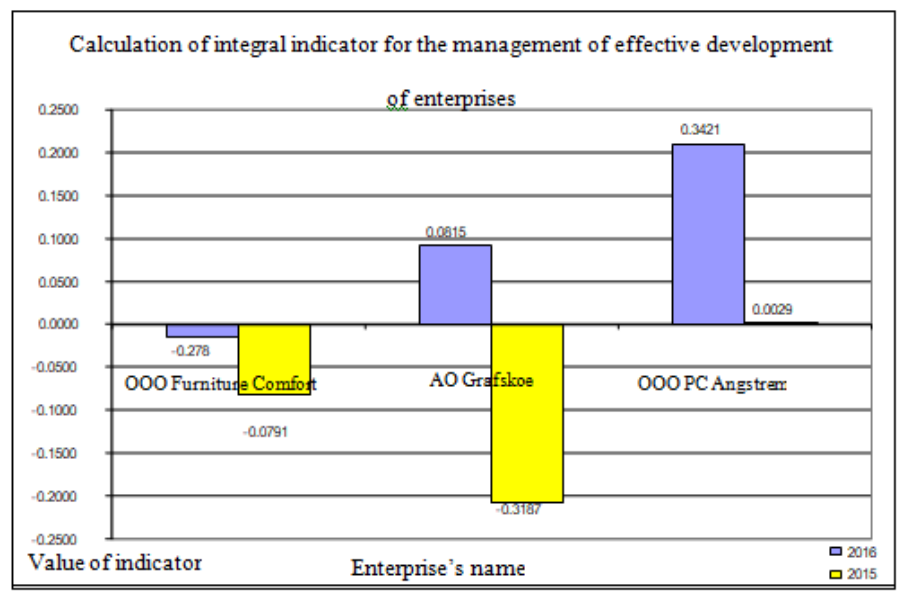

Fig. 1. Effective development of financial and economic activities of enterprises

TABLE III. MATRIX SYSTEM OF FACTOR LOADINGS OF BASIC INDICATORS FOR ASSESSING THE EFFECTIVE DEVELOPMENT OF ENTERPRISES

\begin{tabular}{|c|c|c|}
\hline Indicators & e1 & e2 \\
\hline X01 & 0.289 & 0.731 \\
\hline $\mathrm{X} 02$ & 0.671 & 0.343 \\
\hline $\mathrm{X} 03$ & 0.821 & 0.231 \\
\hline X04 & 0.761 & 0.272 \\
\hline $\mathrm{X} 05$ & 0.351 & 0.667 \\
\hline X06 & 0.451 & 0.579 \\
\hline X07 & 0.161 & 0.841 \\
\hline X08 & 0.181 & 0.814 \\
\hline X09 & 0.591 & 0.421 \\
\hline $\mathrm{X} 11$ & 0.601 & 0.421 \\
\hline X01 & 0.609 & 0.411 \\
\hline $\mathrm{X} 12$ & 0.331 & 0.664 \\
\hline $\mathrm{X} 13$ & 0.533 & 0.491 \\
\hline $\mathrm{X} 21$ & 0.787 & 0.259 \\
\hline $\mathrm{X} 22$ & 0.849 & 0.181 \\
\hline $\mathrm{X} 23$ & 0.271 & 0.739 \\
\hline $\mathrm{X} 24$ & 0.481 & 0.521 \\
\hline $\mathrm{X} 25$ & 0.581 & 0.431 \\
\hline $\mathrm{X} 26$ & 0.661 & 0.341 \\
\hline $\mathrm{X} 27$ & 0.415 & 0.631 \\
\hline $\mathrm{X} 28$ & 0.578 & 0.487 \\
\hline $\mathrm{X} 31$ & 0.363 & 0.641 \\
\hline X32 & 0.281 & 0.741 \\
\hline X33 & 0.371 & 0.649 \\
\hline X34 & 0.441 & 0.551 \\
\hline $\mathrm{X} 35$ & 0.151 & 0.876 \\
\hline X36 & 0.279 & 0.756 \\
\hline X37 & 0.121 & 0.879 \\
\hline X38 & 8.7802 & 14.5403 \\
\hline $\begin{array}{l}\frac{1}{n} \sum_{r=1}^{n} \lambda_{r}=\frac{1}{47} \sum_{r=1}^{2} \lambda_{r} \\
\text { where n - number of } \\
\text { original features, } \mathrm{m}- \\
\text { number of main } \\
\text { components }\end{array}$ & & 0.5134 \\
\hline
\end{tabular}


In order to simplify the understanding of assessment results based on an integral indicator, the authors propose to use multidimensional factor analysis; this analysis enables one to make classification by integrated indicators, which is a linear combination of baseline indicators, rather than basic indicators. The authors used applied component analysis, and 2 main components have been obtained with its help, interpreted in the following sequence: e1 - efficient use of resources in current activities of enterprises, e 2 - effective management of the current activities of enterprises. The matrix of factor loads is given in Table 3. The values of factor loads were determined by an expert-analytical survey of professional managers for all indicators in the studied enterprises. The matrix of these loads is presented in Table 3.

\section{CONCLUSION}

OOO PC Angstrem shows a positive trend of the integrated indicator of effective development of the enterprise; there has been an increase in the rate of managing the effective development of the enterprise, which enables one to conclude about effective use of resources at the enterprise that are necessary to improve the management of effective development of enterprises.

On the basis of the calculations, it can be concluded that OOO PC Angstrem uses a number of basic tools and methods for managing the effective development of enterprise in such papers as:

- Regulations on Financial and Economic department;

Regulation on Economic and Planning department.

These departments are subordinated to a financial manager. Management of effective development on PC Angstrem must be ensured by:

- Improving the overall financial and economic policy of an enterprise, using the analysis of conditions and trends in the further development of the industry specificity of the enterprises under study.

Improvements and finding the necessary financial and economic strategy for the further effective development of an enterprise in order to adapt its financial and business activities and the management system to constantly changing economic environment in the market conditions, using strategic planning.

Improving monetary policy in an enterprise. It is necessary to constantly develop quarterly, annual forecasts for further effective development of the enterprise with consideration of market needs.

Improvement of enterprise standards (IIS) in the analysis of various activities of the enterprise, as well as IIS, in planning the volume of investments and capital investments, in definition of restrictions for financial investments, improvement of measures for the effective use of financial investments.

Established procedures for the development of measures to increase productivity, reduce production costs and product sales, increase profitability in production, increase profitability, reduce losses and non-production costs.

Established procedures for the development of research, in determining conditions for increasing the level of competitiveness of products and identifying the necessary measures using the obtained results.

Improvement of enterprise standards of statistical accounting of all production and planning and economic indicators of the current activities of the enterprise, systematization of statistical data.

Established procedures for the development of measures to ensure the necessary level of efficiency, reduce costs in production and sale of products, identify possible additional reserves in production.

Improved standards for economic costs for the implementation of further activities of an enterprise, as well as their adjustment to the inflation level.

- Improvement of enterprise standards including the analysis of existing management structures in the enterprise and preparation of recommendations for their further development.

Recommendations for improvement of unified documents, financial and economic standards, use of automated processing of financial documentation in the enterprise.

Negative values of effective development of financial and economic activity are observed at OOO Furniture Comfort, but there is a trend towards improving the level of management of effective development of the enterprise, this situation at the enterprise is caused by a number of internal problems.

AO Grafskoe enterprise has shown average values of the integral indicator.

In AO Grafskoe, the use of tools and methods for managing effective development of an enterprise is also reflected in such documents as: Regulations on financial and economic department and Regulations on planning and economic department, these tools border on the above mentioned instruments. A number of additional tools can be shown:

- the control instrument behind the financial and economic activities of the enterprise is newly created annual commission, which conducts control actions once a year; there is no constant monitoring here, this fact does not contribute to an adequate level of improvement in managing the effective development of the enterprise;

- in order to build an effective system of effective development management and all current activities of the enterprise, the company applies a number of principles of ISO 9001: 2000 international standard. The use of this standard is a positive factor for managing the effective development of the enterprise. Based on the results of the analysis, it can be concluded that the enterprise is 
experiencing an inefficient use of the considered tool based on an international standard. If only this tool is used, then this will not be enough to increase the level of management of the effective development of the enterprise.

The data of analysis results make it possible to reveal the fact that the use of considered tools will not lead to an increase in the level of management of effective development in enterprises. This fact can be explained by the following:

The enterprises do not effectively use the considered tools and methods of managing the effective development of the enterprise;

Tools and methods used at enterprises for managing effective development of an enterprise are not highly efficient in their essence.

Using the results of analysis of the effective use of labor resources, the current wage system and reviewed regulatory documents, we can conclude: enterprises have no link of managerial wages to the results of current activities; there are no established goals for many managerial managers.

Based on the above, the process of analyzing the studied enterprises can identify the fact that only its individual elements are implemented in practical application in the existing mechanism for managing the effective development of enterprises with a probable degree of effective functioning, and there is no complete mechanism. This fact has a negative impact on the effective development of enterprises. The authors have highlighted the most problematic elements of the mechanism for managing effective development of enterprises:

imperfection of the methodology for the formation of the mechanism for managing the effective development of enterprises, which may cause absence of elements of considered mechanism necessary at one time or another;

imperfection of models of the mechanism for managing effective development of enterprises, which may cause inconsistent actions between various elements of the mechanism under consideration.

Based on the study of the problems and practices of functioning of the effective development management mechanism, the authors identified the most important areas for further improvement of the management mechanism for the effective development of enterprises:

1. It is necessary to develop a methodology for evaluating management of effective development of enterprises from the perspective of maximizing the use of resources in enterprises. The developed methodology should contribute to the development and implementation of necessary directions for managing the effective development of enterprises, using the necessary organizational forms and economic methods. When improving the mechanism, it is necessary to use provisions on formation and further implementation of the improved mechanism for managing effective development of enterprises.
It is necessary to understand the position of administrative norms and rules used in solving problems related to the management of the effective development of an enterprise in the essence of this classification.

2. It is necessary to develop an algorithm for making management decisions in the direction of improving business processes in enterprises, since an improved mechanism for managing the effective development of enterprises does not provide a very clear understanding of how and in what sequence elements should be introduced into the functional system in enterprises.

3. An important point is development of the reengineering process of the management of effective development in the activities of enterprises, aimed at improving the management of effective development of enterprises, since the essence of reengineering of business processes is a radical change in business processes in order to obtain maximum economic effect of financial and economic activities.

\section{References}

[1] Yu.P. Anisimov, N.V. Sirotkina, Innovatsionnye podkhody k upravleniyu promyshlennymi ob"ektami na osnove sistemy indikatorov, Gos. obl. obrazovatel'noe uchrezhdenie vyssh. prof. obrazovaniya «Voronezhskii in-t innovatsionnykh sistem». Voronezh, 2008, 144 p.

[2] K.V. Baldin, Upravlenie riskami v innovatsionno-investitsionnoi deyatel'nosti predpriyatiya: uchebnoe posobie, Risk management in innovative and investment activity of the enterprise: manual. M.: Dashkov i K, 2012, 420 p.

[3] T.L. Bezrukova, Yu.N. Stepanova, I.I. Shanin, Yu.V. Busarina, S.Yu. Nesterov, Aspect -oriented Key -Index Based Regional Business Entities Evaluation Framework, European Research Studies Journal, 2017, vol. 20, № 3B, pp. 183-192.

[4] F. De Melo, V.V. Maslennikov, E.V. Popova, T.L. Bezrukova, I.V. Kyksova Quantitative analysis in economics based on wavelet transform: a new approach, Asian Social Science, 2015, Vol. 11, № 20, pp. 66-73.

[5] D.A. Endovitskii, N.V. Sirotkina, A.Yu. Goncharov, The analysis of dualism of economic interests in the context of a problem of ensuring the balanced development of the region. Region: systems, economy, management., 2014, No. 3 (26), pp. 19-26.

[6] Yu.V. Zhuravlev, Regularities of process of regulation of business. Theoretical and applied questions of economy and services sector, 2013, No. 12-1, pp. 20-29.

[7] I.V. Kuksova, Ekonomicheskaya diagnostics of elements of innovative capacity of the enterprises under favorable conditions. Management of innovations: theory, methodology, practice. 2014, No. 8, pp. 7-11.

[8] S.S. Morkovina, M.V. Drapalyuk, P.M. Evlakov, N.A. Safonova, Innovational mechanisms of biotechnologies support in forest sector for providing economic security of the state, Asian social science, 2015, Vol. 11, № 20, pp. 41-48.

[9] V.O. Moseiko, S.A. Korobov, D.P. Frolov, Socio-economic systems' competitiveness assessment method, Asian Social Science, 2015, Vol. 11, № 20, pp. 1-8.

[10] Pozdeev, V.L. Methods of the analysis of cyclic fluctuations in economic researches. V.L. Pozdeev. -M.: «Ogrservis -2000», 2007. $-186 \mathrm{p}$.

[11] V.N. Parakhina, Multiplicative effect of application of an innovative form of the organization of economic systems. Innovative Messenger Region, 2012, no3, pp. 1-6.

[12] V.O. Pozdeev, About cyclic fluctuations in economy. Problems of the theory and practice of management, 2006, no. 9, pp. 28-40. 
[13] E.G. Popkova, A.V. Sharkova, M.P. Merzlova, E.A. Yakovleva, A.Y. Nebesnaya, Unsustainable models of regional clustering, World Applied Sciences Journal, 2013, Vol. 25, № 8, pp. 11741180

[14] M.B. Radievskii, M.V. Radievskii, Organization of production: innovative strategy of a sustainable development of the enterprise: Textbook, M.: INFRA-M, 2009, 377 p.

[15] T.Yu. Shemyakina, Control system of innovative activity of the enterprise: studies, Grant. - 2-e izd., dop, M.: FLINTA: Nauka, 2012, 268 p.

[16] N.V. Sirotkina, D.N. Lesnykh, A.I. Matveev, System approach to an assessment of efficiency of management personnel of the industrial enterprise, Economic analysis: theory and practice, 2007, no. 2, pp. 55-56.

[17] Y.N. Stepanova, I.V. Sibiryatkina, V.E. Sukhova, Risk aspects of creation of investment e-platform as a tool of support for small innovative enterprises, Asian Social Science, 2015, Vol. 11, № 20, pp. 127-133.

[18] I.I. Shanin, O.A. Boris, Modeling operation of mechanism of holistic management of technological processes at enterprise, IOP Conference Series: Materials Science and Engineering conference proceedings, 2018, pp. 022095.

[19] S.S. Morkovina, Y.M. Sokolinskaya, N.M. Bukhtoyarov, N.A. Safonova, Deformation factors of the entrepreneurship development in the industry segments of the economy of the Russian Federation, European Research Studies Journal., 2017, vol. 20, № 3B, pp. 403-411. 